\title{
Perspectiva
}

\author{
SUMÁRIO \\ CULTURA: VIDA E POLÍTICA \\ Cultura e Modernidade no Brasil $\mathbf{3}$ \\ Ruben George Oliven \\ Intelectuais e Romantismo Revolucionário $\mathbf{1 3}$ \\ Marcelo Ridenti \\ Violência Fundadora e \\ Violência Reativa na Cultura Brasileira 20 \\ Ciro Marcondes Filho
}

Cultura Popular: entre a tradição e a transformação $\mathbf{2 8}$

Vivian Catenacci

Culturas em Transformação: os índios e a civilização $\mathbf{3 6}$

Clarice Cohn

Novas Fronteiras e Novos Pactos para o Patrimônio Cultural 43

Cecilia Rodrigues dos Santos

Guia Cultural: uma introdução 49

Equipe Técnica do Guia

O Espaço da Cultura: Guia Cultural do Estado de São Paulo $\mathbf{5 5}$ Aurílio Sérgio Costa Caiado

Cultura como Objeto de Política Pública $\mathbf{6 6}$

José Carlos Durand

Dimensões da Cultura e Políticas Públicas 73

Isaura Botelho

A Merencória Luz do Estado 84

Carlos Alberto Dória

O Educador: magnanimidades e ambigüidades $\mathbf{9 2}$

Fernando José de Almeida

\section{NOTA DO EDITOR}

Atualmente, vive-se uma época na qual a dimensão cultural ganha proeminência inusitada e invade diferentes esferas da sociedade, introduzindo-se de maneira específica no cotidiano das pessoas e tornando-se uma área de interesse crescente por parte do Estado e de outras instituições civis.

Verifica-se uma dinâmica cultural, marcada por hibridismo nas relações entre práticas culturais e lógicas políticas e econômicas, levando alguns pensadores a afirmarem que a atual fase do capitalismo vem sendo marcada por uma tendência predominantemente cultural. Além disso, na atualidade, ocorre uma série de confrontos ou complementações entre diferentes tipos de culturas, defesas do multiculturalismo ou até da intransigência cultural, bem como debates acerca das relações entre cultura local/nacional e aquela internacionalizada e midiática.

Daí o interesse crescente que a área cultural desperta entre agentes públicos ou privados que buscam direcionar as suas ações para incrementá-la e gerar debates em sua defesa ou para compreensão das suas particularidades.

Dada a relevância deste entrecruzamento entre vida e política, propiciado pela cultura, diante da importância de se conhecer os mecanismos da formulação de uma política cultural e a valorização de práticas internas da produção ou criação cultural, São Paulo em Perspectiva elegeu o tema cultura como foco de discussão. Este número analisa esta área do ponto de vista externo, apresentando artigos que examinam amplos processos culturais, preocupados tanto em conceituações quanto em identificar as mais diferentes expressões culturais do país. Outros artigos oferecem ao leitor abordagens sobre patrimônios e pesquisas culturais, além de um consistente conjunto de textos que têm como eixo as políticas públicas e o papel do Estado enquanto importantes agentes na dinâmica e estruturação cultural no Brasil.

Este enfoque geral e direcionado para ações culturais dará lugar, no próximo número, a análises de aspectos específicos, ligados a questões internas da produção desta área. 